\title{
EVALUATION OF EDUCATION AND TRAINING PROGRAM AT MEDAN RELIGIOUS TRAINING CENTER
}

\author{
Rahmadi Ali ${ }^{1}$, Rofiqoh Hasan Harahap ${ }^{2}$ \\ ${ }^{1}$ Early Childhood Education Department, Universitas Muslim Nusantara Al Washliyah, \\ Medan, North Sumatera, Indonesia \\ 2Physics Education Department, Universitas Muslim Nusantara Al Washliyah, \\ Medan, North Sumatera, Indonesia \\ Email: rahmadiali@umnaw.ac.id ${ }^{1}$, rofiqohhasan@umnaw.ac.id²
}

DOI: http://doi.org/10.33650/al-tanzim.v5i2. 2014

\begin{tabular}{l|l|l} 
Received: March 2021 & Accepted: July 2021 & Published: August 2021
\end{tabular}

\begin{abstract}
:
This study aims to analyze and evaluate the context, input, process, and product of a substantive technical training program for preparing lesson plans for Madrasah Ibtidaiyah teachers. The study used a qualitative approach with the CIPP evaluation model (context, input, process, and product). The results showed that; first, the context dimension states that the implementation of education and training is by the legal basis for working; second, the input dimension includes the availability of reliable resources, adequate facilities, and infrastructure and financing borne by the government, so that its implementation can be carried out properly; third, the dimension of the process which includes the implementation of programs that are by the predetermined plans and designs; fourth, the product dimension where the teacher already understands the specified competencies.
\end{abstract}

Keywords: Program Evaluation, Teacher Competence, Religious Training Center

\begin{abstract}
Abstrak:
Penelitian ini bertujuan untuk menganalisis dan memahami tentang bagaimana mengevaluasi konteks, input, proses dan produk program pelatihan teknis substantif penyusunan RPP bagi guru Madrasah Ibtidaiyah. Penelitian menggunakan pendekatan kualitatif dengan model evaluasi CIPP (context, input, process dan product). Hasil penelitian menunjukkan bahwa; pertama, dimensi konteks menyatakan bahwa penyelenggaraan diklat sesuai dengan landasan hukum dalam bekerja; kedua, dimensi input meliputi tersedianya sumber daya yang handal, sarana dan prasarana yang memadai dan pembiayaan yang ditanggung oleh pemerintah, sehingga pelaksanaannya dapat dilakukan dengan baik; ketiga, dimensi proses yang meliputi pelaksanaan program yang sudah sesuai dengan rencana dan desain yang telah ditentukan; keempat, dimensi produk di mana guru sudah memahami tentang kompetensi yang ditentukan.
\end{abstract}

Kata Kunci: Evaluasi Program, Kompetensi Guru, Balai Diklat Keagamaan 


\section{INTRODUCTION}

One of the factors in the implementation of development is human resources (HR) (Sondang, 2015; Dakir, 2019). Development inputs such as natural resources, materials, and funding sources will not provide optimal benefits if adequate human resources do not support them, both in quality and quantity.

According to Siagian (2015) that human resources planning is a function that must first be carried out in the organization. Human Resources planning is specific steps taken by management to ensure that the organization has the right workforce available to occupy the correct positions, positions, and jobs at the right time. All of this is to achieve the goals and various targets that have been and will be set (Öztürk, 2016; France-Harris et al., 2019). Procurement is in the form of a withdrawal, selection, and placement process to get employees according to the company's needs. Control in activities to control all employees to comply with company regulations and work according to plan (Chiedozie et al., 2018). The development is in the form of improving the technical, theoretical, conceptual skills of all employees through education and training (Cobanoglu et al., 2018).

According to Cushway (1992), that is a systematic and continuous process of analyzing organizational needs for human resources in changing conditions and developing personnel policies that are by the organization's long-term plans. It is an integral part of the company's planning and budget because financing and human resource estimates will affect and be influenced by the company's long-term plans.

According to DeCenzo (2005), human resource management has supporting factors. The usefulness of HR is needed in every organization, including; planning, organizing, directing, procurement, 5) control, development, maintenance, and integration. Then, in reality, the practice of human resource management is different in each country. The same thing was also conveyed by Ozutku and Ozturkler (2009), that these differences are divided into two dimensions, namely external and internal. The external dimensions are; economic, technological, national culture, industry/sector characteristics, legislation/ regulation, competitors' actions, union actions, and globalization. While the internal dimensions are; organizational size, organizational structure, business strategy, human resource strategy, history, traditions and past practices, top management, line management, power, and politics.

Then to understand the meaning of HR, it is necessary to distinguish between macro and micro meanings. Experts divide the notion of HR into two, namely the understanding of macro and micro. The definition of human resources at a macro level is all humans as residents or citizens of a country or within certain territorial boundaries who have entered the age of the workforce, both those who have or have not obtained work (employment). Understanding $\mathrm{HR}$ in a simple micro sense is humans or people who work or become members of an organization called personnel, employees, employees, workers, labor, and others (Nawawi, 2003). 
The explanation of humans as resources shows that humans are unique and complex creatures. Working in a company environment must be treated with a good quality of work-life to enable them to work effectively, efficiently, productively, and with quality. Among them are providing opportunities to develop their careers, being treated fairly in resolving the conflicts they face, being supervised honestly and objectively, getting decent wages, and others (Mangkunegara, 2001). In reality, human resources and organizations / institutions as a forum to realize humanity's nature and meet human needs have a solid relationship.

Maginson (1993) states that the quality of human resources is determined by various interrelated factors, including health and ability. The ability factor as one of the determinants of the quality of human resources can be developed, including through education. So, education is an effort in the process of developing human resources.

Human resource development can be done by holding regular education and training (Merve \& Cagda, 2018). Education and training are carried out so that human resources can always follow the development of science and technology (Siddik \& Kawai, 2020; Miskiah et al., 2019). Investment in education and training can be the primary catalyst for human resource development in HR management (Silviani et al., 2021), assuming that the more educated and trained HR is, the higher the level of HR awareness and participation in organizations or companies. Education and training create an environment where human resources can acquire or learn attitudes, abilities, skills, knowledge, and behaviors related to their work (Martoyo, 2000).

The purpose of education and training is closely related to the type of organization, company, institution, and agency. According to Martoyo (2000), the purpose of education and training is to improve the level of effectiveness of employee activities and employees in achieving the results set. Meanwhile, according to Nitisemito (1992) that the objectives of education and training are; 1) jobs are expected to be completed faster and better; 2) responsibilities are expected to be more significant; 3 ) errors in work are expected to be reduced; 4) the continuity of the company is expected to be more guaranteed; 5) Based on the opinion above, it can be explained that the purpose of education and training is to improve human resources in quality. Of course, this will have an impact on increasing the productivity of a company or institution.

Education and training are two terms that are almost the same in terms of meaning and implementation (Chimpololo, 2019). However, the scope, characteristics, and objectives of the performance are different. Education means a process to influence students to adapt as best they can to their environment (Hamalik, 2008). In the Law on the National Education System Number 20 of 2003, it is stated that "education is a conscious and planned effort to create a learning atmosphere and learning process so that students actively develop their potential to have religious-spiritual strength, self-control, personality, intelligence, morals. Noble, as well as the skills needed by himself, society, nation, and state. 
Meanwhile, training means an effort to increase knowledge, develop attitudes, develop skills of members, mainly to deal with change, generate motivation, support, feedback, and integrate the psychomotor application of theory and practice (Handoko, 2001). According to Rivai (2004), training systematically changes employee behavior to achieve organizational goals. Training relates to the skills and abilities of employees to carry out current jobs. Training has a current orientation and helps employees acquire specific talents and abilities to carry out their assignments successfully.

From the experts' opinions above, it can be concluded that Education and Training (Training) is a program that is expected to provide a stimulus to someone to improve their abilities in specific jobs. Job Training is usually associated with education. This is mainly because, conceptually, training cannot be separated from education. Although specifically, training can be distinguished from education. Training is a form of education with learning principles. The presence of the Medan Religious Education and Training Center provides a breath of fresh air as an educational and training institution for teachers. Its company is expected to enlighten teachers regarding the lack of knowledge and ability of teachers to improve their professionalism.

The education and training programs carried out at the Medan Religious Education and Training Center should positively impact the development and progress of human resources. Because with the Religious Education and Training Center, the quality of the human resources is getting more advanced. Especially in the field of education, BDK is here to answer the low quality of educators in the Ministry of Religion. The Medan Religious Education and Training Center provides education and training for administrative staff and technical education, and religious personnel.

To see whether the programs organized by the Medan BDK are very useful or not, both in terms of curriculum, effectiveness, and efficiency, it is necessary to evaluate these programs. These programs are assessed from the aspect of context, input, process, and product. Program evaluation is not to find errors but rather to improve (Elistanto \& Mahmudah, 2020; Prengki, 2019). It may be that the programs that have been implemented contain elements of failure, so there is a process for assessment (Hefniy et al., 2019).

This research is program evaluation research. The program that will be evaluated using the CIPP evaluation model is the Substantive technical training program for the Preparation of Islamic Education Teacher Training Plans (RPP) at the Medan Religious Education and Training Center. The researcher's desire to research the evaluation of the education and training program because there are many pieces of training held at BDK Medan, including training to increase the competence of madrasa teachers is valid or not.

However, this research will focus on the substantive technical training for the preparation of the RPP for Madrasah Ibtidaiyah teachers in the form of; 1) The context of the substantive technical training program for the preparation of the RPP for Madrasah Ibtidaiyah teachers, what is the background of the program, and how is the organization of the training; 2) Program input, such as a professional widyaswara, the requirements needed to become a widyaswara, 
the facilities and infrastructure needed, and the available funding; 3) The process in the program that has been determined runs according to plan or not, then the performance of the widyaswara and training participants; 4) The product of the substantive technical training program for preparing the RPP for Madrasah Ibtidaiyah teachers has been fulfilled from the training program that was held. Based on the analysis above, the researcher believes that there is a need for an evaluation of these programs, especially the madrasa teacher competency improvement program. The CIPP model is widely used to evaluate programs running, one of which is research conducted by Azmi (2020) with the title Evaluation Of The Process Of Implementing Tahfidz Al-Qur'an Learning Programs In Integrated Islamic Basic Schools of DOD Deli Serdang. In his research, he stated that when CIPP is used, we will know whether the program can be continued or stopped altogether.

Therefore, the main focus as the main target of this program evaluation research is a critical analysis of several factors as determinants and benchmarks for the success or failure of a program being implemented, including; 1) The context of the substantive technical training program for the preparation of the RPP for Madrasah Ibtidaiyah teachers; 2) The condition of input for the substantive technical training program to prepare the RPP for Madrasah Ibtidaiyah teachers; 3 ) The substantive technical training program's condition for preparing the RPP for Madrasah Ibtidaiyah teachers; 4) The condition of the product of the Substantive technical training program for the preparation of the RPP for Madrasah Ibtidaiyah teachers.

\section{RESEARCH METHODS}

This type of research is descriptive qualitative research. So the research procedure will produce descriptive data in the form of written or spoken words from people and observable behavior. This qualitative descriptive study aims to detect a situation or phenomena as they are Sukmadinata (2007). The evaluation model that the researcher chose was the CIPP model evaluation (context, input, process, product). The researcher uses the CIPP evaluation model is because this model is more comprehensive than the existing evaluation model. In addition, the evaluation of the CIPP model will end with recommendations from researchers, including; 1) The Substantive Technical Training Program The preparation of the RPP for Madrasah Ibtidaiyah teachers at the Medan Training Center was successful and can be continued; 2) Substantive Technical Training Program The preparation of the RPP for Madrasah Ibtidaiyah teachers at the Medan Training Center was continued with improvements; 3) The Substantive Technical Training Program for the preparation of the Madrasah Ibtidaiyah Teacher RPP at the Medan Training Center was stopped, Sukardi (2015).

Then, in addition to providing recommendations for the madrasah teacher competency improvement program at the Medan Education and Training Center, the CIPP evaluation will also reveal the program's strengths and crucial issues in each program implementation. The program evaluated in this study was only focused on Substantive Technical Training for the Preparation of Teacher Training Plans for Madrasah Ibtidaiyah Classes at the Ministry of Religion of North Sumatra Province in 2020. In this study, the 
chosen research background was evaluating the madrasa teacher competency improvement program at the Medan Religious Education and Training Center. The location of this research is natural. This is in Patton's opinion in Syafaruddin (2004) that qualitative design is naturalistic, where researchers do not try to manipulate the research setting. Still, the research setting is a natural event, program, relationship, or interaction that is not forced to build problems for researchers. To collect data, the researchers used several techniques in data collection, including observation., interview, and documentation. The data is analyzed, then there are several techniques to analyze the data, including; data condensation., data display, and concluding.

\section{RESULTS AND DISCUSSION}

\section{Context Aspects of the Substantive Technical Training Program}

In this aspect, two components become the core of this research, namely, First. There is a legal basis for every training activity organized by Religious Education and Training Centers throughout Indonesia. In the implementation of education and training organized by the Medan BDK, the legal umbrella must first be prepared so that in its performance, it does not seem arbitrary and the goals achieved are by the laws in force in our country. The legal foundations are; 1) RI Law Number 5 of 2014 concerning State Civil Apparatus (ASN); 2) RI Government Regulation Number 11 of 2017 concerning Management of Civil Servants; 3) Regulation of the Minister of Religion of the Republic of Indonesia Number 42 of 2016 concerning Organizations and Work Procedures of the Ministry of Religion; 4) Regulation of the Minister of Religion 10 of 2018 concerning PMA No. 59 of 2015 concerning the Organization and Work Procedures of Religious Education and Training Centers; 5) Decree of the Minister of Religion of the Republic of Indonesia Number 75 of 2015 concerning the Implementation of Education and Training of Employees at the Ministry of Religion; 6) Decree of the Head of Research and Development and Training of the Ministry of Religion Number 62 of 2017 concerning Curriculum Education and Training of Educational and Religious Technical Personnel; 7) Decree of the Minister of Religion Number 148 of 2014 concerning Determination of Honorarium for Non-PNS Religious Counselors; 8) DIPA of Medan's Religious Education and Training Center 2020 Number. 025.11.425350/2020 January 05, 2020. Second. There is a training organization. The education and training organization at BDK Medan has work indicators, namely determining the goals and objectives of the training, determining the education and training curriculum, determining the training participants, determining the widyaswara/teaching staff, and evaluating all components of the movement (committee, participants and widyaswara).

\section{Input Aspects of the Substantive Technical Training Program}

In this aspect, three main components are the core of this research, including the first-criteria for human resources. There are two focuses of discussion in this HR criteria: the determination of widyaswara and the requirements to become a widyaswara. The teaching staff / Widyaswara who teach in the Substantive Technical Training program for preparing the MI 
Teacher RPP of the Ministry of Religion in 2020 are professional people. As explained in the theoretical study, one of the experienced indicators of a teacher is mastery of learning materials.

Related to the requirements to become a resource person/widyaswara, namely, First, must be ASN, meaning that the people who will become presenters at the Medan BDK must have the status of a Civil Servant at least having the rank/class of stylist-III/c. Second, Have a minimum Master's degree because what will be faced by the widyaswara / resource person is a teacher who has a minimum S1 degree, so the widyaswara must have a Master's degree. Third, have positions in their respective work units. Fourth, have experience in the training subjects that will be taught. Fifth, if the lecturer is an expert in a particular field. Sixth. If a teacher, then he must have a position as a school principal, by the procedures that have been set and contained in the Regulation of the Ministry of Empowerment of State Apparatus and Bureaucratic Reform of the Republic of Indonesia Number 22 of 2014.

\section{Aspects of the Substantive Technical Training Program Process}

An essential component in this research is the criteria for implementing the madrasa teacher competency improvement program at the Substantive Technical Training and Preparation of Class MI Teacher RPP at the Medan Religious Education and Training Center, namely;

First, implementation of the training program as planned. At this point, the researcher gave a good score because the researcher assessed that the implementation of this training program was in accordance with what was planned. This is based on the results of interviews; none of the participants complained about the training schedule. The researchers saw that each participant had started arriving one day to attend the training based on observations. After the training participants came, they immediately registered in the registration room; then, the committee directed them to enter the dormitory. Based on the documentation study, the researcher saw that everything went according to plan, starting from notification letters (invitations to participants) sent via email to each work unit (Ministry of Religion of North Sumatra, everything went according to plan.

Second, widyaswara/teaching staff master the learning method. In the Widyaswara aspect, the researcher gave sufficient value. The researcher saw that the method used by widyaswara was only the classical method in delivering the material, namely the lecture method and the assignment method. Researchers have not found a new technique used by widyaswara in conveying the material. So this method is a method commonly used by teachers. Then based on the results of interviews with participants, the widyaswara/teaching staff always use the lecture method.

Third, widyaswara/teaching staff use learning media. In this aspect, the researcher gave a good score. This is based on the first two things based on interviews with participants that the media used by the widyaswara/teaching staff is entirely satisfactory starting from the focus, modules, and other media adapted to their respective materials. Likewise, with the researcher's observation that the widyaswara/teaching staff use a lot of learning media in 
delivering their material, the media are in the form of focus, modules, and media adapted to the material.

Fourth, training participants create study groups. in this aspect, the researcher gave a good score. This is because the training participants are very enthusiastic when instructed by the widyaswara/teaching staff to create study groups, so the training participants immediately make study groups. From the results of the researcher's observations that every widyaswara/teaching staff always applies this method during practicum material. Because the training participants are required to practice all forms of material presented by the widyaswara/teaching staff.

Fifth, training participants practice making lesson plans. In this aspect, the researcher gave a good score. Based on the results of the interviews, each training participant was trained and asked to prepare lesson plans. Training participants are given an understanding of the aspects contained in the RPP and then guided on the procedures for formulating objectives, essential competencies, core competencies, and other aspects in the RPP. After all the theory is given to the participants, then the participants practice preparing lesson plans for one subject.

\section{Product aspects of the Substantive Technical Training program}

In this aspect, there are seven essential components in this research, namely; First, Teachers can understand core competencies and essential competencies. At this point the researcher gave a low score because from the results of interviews with alumni teachers of the preparation of lesson plans, the teacher only knew that KI and KD were stipulations from the government, but when asked about the meaning and explanation the teacher could not explain in detail. Even from the explanation, the teacher was impressed with the origin in answering the questions from the researcher. On this basis, the researcher concludes that teachers do not understand what is meant by Core Competencies and Basic Competencies.

Second, teachers can formulate indicators. At this point, the researcher gave a good score because the teachers have been able to develop indicators per field of study. The interviews above show that teachers already know the placement of words for hands in each area of study. Indicators are formulated using active verbs that can be measured. Then based on the analysis of the lesson plan documentation, it was found that active verbs were found in the learning indicators.

Third, the teacher can formulate learning objectives. In this component, the researcher gave a good score because some of the teachers interviewed by the researcher understood how to develop learning objectives. After all, the learning objectives were emphasized on the student center, which was based on students. Then based on the study of lesson plans, the researcher saw that the teacher could formulate learning objectives well. Then in the RPP, the researcher saw that the learning objectives made had been adjusted to the instructional goals set by the government. 
Fourth, the teacher can determine the learning method. This component gives a good value because, in the interview, the researcher said that the teacher already understood what way would be used in learning. The use of these methods varies according to the learning needs of each field of study. Then in the RPP document that the researcher saw, it was noted that several plans had been determined in learning, including the lecture method, demonstration method, assignment method, practice method, and several other methods.

Fifth, teachers can arrange learning activities. In this component, the researcher gave a good score because the teachers have been able to put learning activities. In this learning activity, the main content of the lesson plan is. In this learning activity, learning is packaged. Then in this learning activity, it will be determined how the preliminary, core and closing activities will be. In the core activity, the exploration cycle is written. The teacher involves students in finding and collecting information, using media to enrich the experience of managing data, facilitating students to interact so that students are active. Then the elaboration cycle, where the teacher encourages students to write the results obtained through exploration activities, discussing, hearing opinions to explore something further-analyzing the strengths or weaknesses of arguments, deepening knowledge about something, building agreements through cooperative and collaborative activities. Then the confirmation cycle, namely, the teacher provides feedback on students' produced or done through the learning experience. The teacher gives appreciation to students for their work.

Sixth, teachers can determine learning resources and media. In this component, the researchers gave a good score; this is because, based on the results of interviews with teachers, first, they were able to distinguish between learning resources and learning media. Secondly, they can choose which are learning resources and which are learning media. In the RPP document, the researchers saw that the learning resources they chose were books, resource persons. At the same time, the learning media they chose were laptops, projectors, and other media. So based on this, the researcher gave a good score. The teacher can make an assessment.

\section{CONCLUSION}

The research concludes that the evaluation of the context, input, process, and product of the substantive technical training program for the preparation of the RPP for Madrasah Ibtidaiyah teachers at the Medan Religious Education and Training Center has gone well so that it can provide maximum results for teachers in developing their competencies properly. This is due to a comprehensive and detailed planning design, both for the participants and for the resource persons. Meanwhile, in the aspect of implementation, all activities are carried out concerning the planning design that has been determined, both to be carried out by participants and by Widyaswara, so that the implementation runs effectively and efficiently. The results of the activity showed that the training participants had understood the material presented by Widyaswara well. 


\section{REFERENCES}

Azmi, F. (2020). Evaluation of The Process of Implementing Tahfidz Al-Qur'an Learning Programs in Integrated Islamic Basic Schools of Dod Deli Serdang. Edukasi Islami: Jurnal Pendidikan Islam, 9(2), 4-7

Chiedozie, O. L., Victor, A. A., \& Sunday, F. T. (2018). Relationship between Staff Human Resource Management and Academic Performance of Accounting Students in Secondary Schools in Akoko South-West, Ondo State. Online Submission, 4(8), 31-41. Retrieved from http://escweb.lib.cbs.dk/login?url=http:// search.ebscohost.com/login.aspx?direc $\mathrm{t}=$ true\&db=eric\&AN=ED586261\&site=ehost-live

Chimpololo, A. (2019). An Analysis of Heutagogical Practices through Mobile Device Usage in a Teacher Training Programme in Malawi. Journal of Learning for Development, 7(2), 190-203. Retrieved from http:/ / oasis.col.org/handle/11599/3388

Cobanoglu, F., Sertel, G., \& Sarkaya, S. S. (2018). Human Resource Management Practices in Turkish Education System (Denizli Case). European Journal of Educational Research, 7(4), 833-847. https://doi.org/10.12973/eujer.7.4.833

Dakir. (2019). Manajemen Pemasaran Lembaga Pendidikan Islam. Yogyakarta: KMedia.

Darma, K. (2019). The Effectiveness of Teaching Program of CIPP Evaluation Model: Department of Mechanical Engineering, Politeknik Negeri Bali. International Research Journal of Engineering, IT E Scientific Research, 5(3), 236-254

Elistanto, R., \& Mahmudah, F. (2020). Evaluasi Efektivitas Manajemen Pembelajaran Guru Produktif Otomotif SMK. Jurnal Studi Manajemen Pendidikan, 4(1), 102-115.

France-Harris, A., Burton, C., \& Mooney, M. (2019). Putting Theory into Practice: Incorporating a Community Engagement Model into Online Pre-professional Courses in Legal Studies and Human Resources Management. Online Learning Journal, 23(2), 21-39. https://doi.org/10.24059/olj.v23i2.1448

Hamalik, O. (2008). Pendidikan Guru Berdasarkan Pendekatan Kompetensi. Jakarta: Bumi Aksara.

Hefniy, Fauzi, A., Faridy, \& Fatmasari, R. (2019). National Assessment Management Based on Information and Communication Technology and its Effect on Emotional Intelligence Learners. Journal of Physics: Conference Series, 1175(1), 9-13. https:/ / doi.org/10.1088/1742-6596/1175/1/012225

Merve, U., \& Cagda, K. C. (2018). Teachers Opinions of Human Resources Management Functions in Private Schools. Educational Research and Reviews, 13(12), 487-494. https://doi.org/10.5897/err2017.3407

Miskiah, M., Suryono, Y., \& Sudrajat, A. (2019). Integration of Information and Comunication Technology into Islamic Religious Education Teacher Training. Cakrawala Pendidikan, 38(1), 130-140. https://doi.org/10.21831/cp.v38i1.23439 
Ningrum, E. (2018). Evaluation of Learning System on Teacher Educational Profession Programs. Jounal Mimbar, 34(2), 123-134

Öztürk, S. (2016). Human Resources Management in Educational Faculties of State Universities in Turkey. International Journal of Environmental and Science Education, 11(5), 931-948. https://doi.org/10.12973/ijese.2016.503a

Prengki. (2019). Evaluasi Program Metode Ummi di SDIT Aliya Bogor. EDU Religia, 3(1), 1-12.

Siddik, M. A. B., \& Kawai, N. (2020). Government Primary School Teacher Training Needs for Inclusive Education in Bangladesh. International Journal of Whole Schooling, 16(2), 35-69.

Silviani, S., Maarif, M. A., \& Wibowo, A. (2021). Knowledge Sharing Management: Strategy for Improving the Quality of Human Resources. Al-Tanzim: Jurnal Manajemen Pendidikan Islam, 5(1), 129-139. https://doi.org/10.33650/al-tanzim.v5i1.1831

Sukardi. (2015). Evaluasi Pendidikan dan Kepelatihan. Jakarta: Bumi Aksara.

Sukmadinata. (2007). Metodologi Penelitian Pendidikan. Bandung: Remaja Rosda Karya. 